\title{
High-latitude obliquity as a dominant forcing in the Agulhas current system
}

\author{
T. Caley ${ }^{1}$, J.-H. Kim ${ }^{2}$, B. Malaizé ${ }^{1}$, J. Giraudeau ${ }^{1}$, T. Laepple ${ }^{3}$, N. Caillon ${ }^{4}$, K. Charlier ${ }^{1}$, H. Rebaubier ${ }^{4}$, \\ L. Rossignol ${ }^{1}$, I. S. Castañeda ${ }^{2, *}$, S. Schouten ${ }^{2}$, and J. S. Sinninghe Damsté ${ }^{2}$ \\ ${ }^{1}$ Université de Bordeaux 1, CNRS, UMR5805, EPOC, Bordeaux, France \\ ${ }^{2}$ NIOZ, Royal Netherlands Institute for Sea Research, Department of Marine Organic Biogeochemistry, \\ 1790 AB Den Burg, The Netherlands \\ ${ }^{3}$ Alfred Wegener Institut (AWI), Bussestrasse 24, 27570 Bremerhaven, Germany \\ ${ }^{4}$ LSCE, Gif-sur-Yvette, France \\ ${ }^{*}$ University of Massachusetts Amherst, Department of Geosciences, 611 North Pleasant Street, 233 Morrill Science Center, \\ Amherst, MA 01003, USA
}

Received: 27 June 2011 - Published in Clim. Past Discuss.: 30 June 2011

Revised: 14 October 2011 - Accepted: 14 October 2011 - Published: 26 November 2011

\begin{abstract}
The Agulhas Current transport of heat and salt from the Indian Ocean into the South Atlantic around South Africa (Agulhas leakage), can affect the Atlantic meridional overturning circulation (AMOC) and, thus, influence global climate. However, efforts to elucidate forcing mechanisms connecting the Agulhas leakage with the upstream dynamics of the current have been hampered by a lack of climate records extracted from the area where the Agulhas current originates. We determine 800-kyr sea surface temperature (SST) and salinity (SSS) records from the "precursor" region of the Agulhas current and show that these records contain strong 100-kyr and 41-kyr cycles. This latter obliquitydriven cycle is nearly in phase with changes in the annual mean insolation and air temperature at high southern latitudes. In contrast, our SST and SSS records did not reveal precession-driven cycles, which is surprising given the lowlatitude location of the upstream Agulhas current. Together, this indicates that the dynamics of the Agulhas current system is mainly controlled by high latitude obliquity through its influence on the position of the Southern Hemisphere subtropical front (STF) and its associated westerlies. Our study demonstrates that obliquity may drive an important part of the 100 kyr cycles observed in the system rather than precession. Our results also suggest that a stronger Agulhas current, associated with a northward shift of the wind system dur-
\end{abstract}

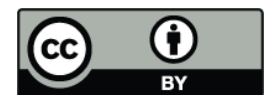

Correspondence to: T. Caley (t.caley@epoc.u-bordeaux1.fr) ing glacial periods, leads to reduced leakage, in accordance with the theory. We argue that during terminations, stronger Agulhas leakage of heat and salt was triggered by increased obliquity exerting a positive feedback on the global climate system through modulating long-term AMOC variations.

\section{Introduction}

The inter-ocean exchange of heat and salt (Agulhas leakage) from the Agulhas current is a key component of the global ocean "conveyor" circulation (Weijer et al., 2002; Gordon, 2003; Lutjeharms, 2006; Beal et al., 2011). Modelling studies show that the Agulhas leakage alters the Atlantic Meridional Overturning Circulation (AMOC) on different time scales. At decadal time scales, perturbations of planetary waves by mesoscale eddies, the so-called "Agulhas rings", affect AMOC variability (Biastoch et al., 2008). Over a period of several hundred years, changes in the buoyancy of Atlantic thermocline waters can influence North Atlantic deep-water formation (Weijer et al., 2001, 2002), with implications for global climate. These later simulations suggest that a saltier Atlantic ocean, linked to a more efficient leakage of warm and saline Agulhas waters, leads to a stronger and more stable AMOC. Accurate knowledge of the mechanisms governing the Agulhas current system under different climatic conditions is essential for properly constraining the long-term AMOC response to the Agulhas leakage

Published by Copernicus Publications on behalf of the European Geosciences Union. 
in climate models (Gordon, 2003), for better understanding the evolution of global climate, and for credible longterm climate predictions. However, long-term sea surface salinity (SSS) records are scarce in the Agulhas system and, to date, most of the sea surface temperature (SST) records were reconstructed either in the Agulhas rings leakage region (Peeters et al., 2004; Martinez Mendez et al., 2010) or outside of the Agulhas current trajectory (Bard and Rickaby, 2009) (Fig. 1). Studies in the Agulhas rings leakage region have shown conflicting results between SST reconstructions, which is perhaps not surprising given the complexity of the studied area with vigorous regional ocean currents, the development of SST contrasts during glacial periods in association with seasonal changes in Agulhas water transport, or lateral shifts of the Agulhas retroflection (Martinez-Mendez et al., 2010). Knowledge of SST and SSS changes in the upstream (precursor) region of the Agulhas current system might provide new insights into this problem. Such knowledge is also important considering that the upstream waters end up in the Agulhas leakage system further downstream and partially flow into the Atlantic Ocean, thereby potentially altering the buoyancy balance of the Atlantic Ocean (Weijer et al., 2001, 2002). In addition, the role of orbital forcing on the dynamics of the Agulhas current system is not completely understood, in particular, the origin of the potential low latitude forcing (strengthen/weaken monsoon) in the Agulhas leakage (Peeters et al., 2004).

Here we utilise a multi-proxy (inorganic and organic geochemical) approach to examine 800-kyr records of SST and surface water $\delta^{18} \mathrm{O}\left(\Delta \delta^{18} \mathrm{O}_{\mathrm{sw}}\right.$, a proxy of regional SSS $)$ from a sediment core located beneath the present "precursor" (upstream) region of the Agulhas current (MD96-2048, $26^{\circ} 10^{\prime} 482^{\prime \prime} \mathrm{S}, 34^{\circ} 01^{\prime} 148^{\prime \prime}$ E, $660 \mathrm{~m}$ water depth, Fig. 1). We examine the effects of SST and SSS variations on changes in the Agulhas current system, strength, and linkages with the Agulhas leakage.

\section{Material and methods}

Core MD96-2048 (37.59m) was collected during the 104 MOZAPHARE oceanographic cruise of the R/V Marion Dufresne. The study was conducted on the top $12 \mathrm{~m}$. The core was retrieved close to Delagoa Bight (Fig. 1). Nowadays, this area often falls under the influence of an eddy, likely driven by the rapid flow of the adjacent waters past the substantial promontory (Quartly and Srokosz, 2004; Lutjeharms, 2006). The occurrence of an upwelling cell at the north-eastern corner of the Delagoa Bight (Quartly and Srokosz, 2004) seems to be less consistent than for similar upwelling cells in the southern limb of the East Madagascar current (Machu et al., 2002) and inshore of the Agulhas current (Lutjeharms et al., 2000).
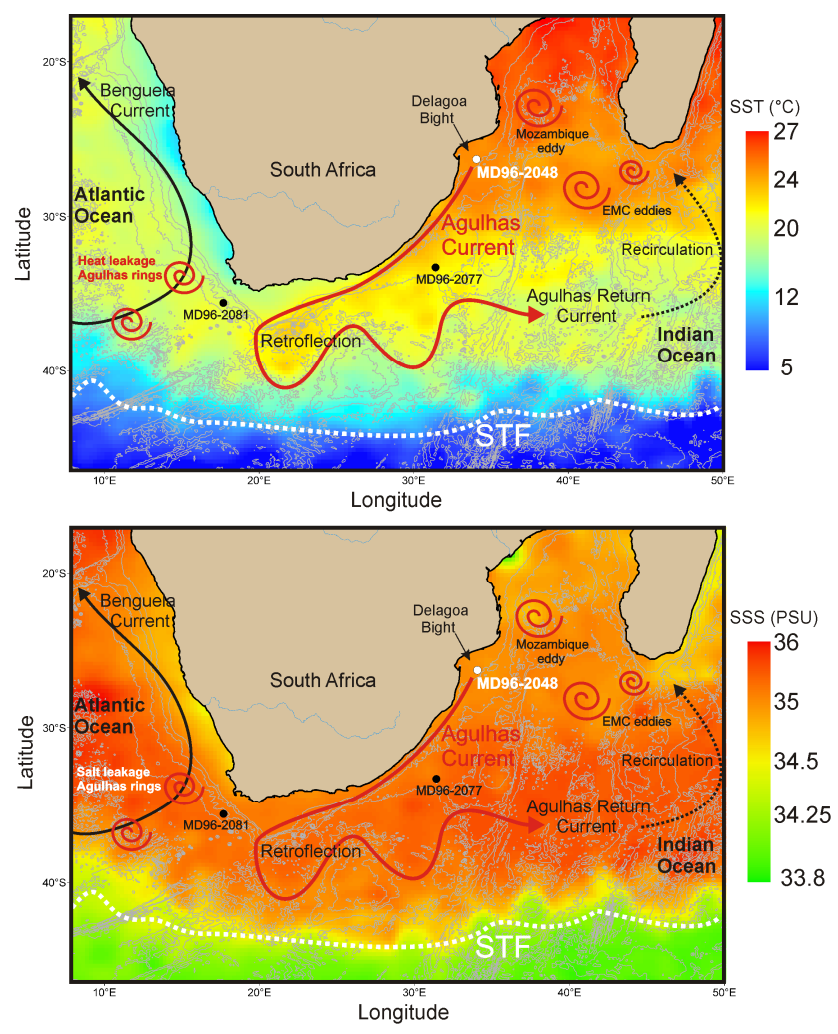

Fig. 1. Heat and salt transfer of the Agulhas surface current. (A) Sea surface temperature (SST) and (B) sea surface salinity (SSS) distribution patterns in the Agulhas system obtained from NODC_WOA94 data provided by the NOAA/OAR/ESRL PSD, Boulder, Colorado, USA, from their Web site (http://www.esrl. noaa.gov/psd/). The location of core MD96-2048 (white dot) and schematic views of the Agulhas current system are indicated. The position of the Subtropical Front (STF) is indicated by the white dashed line. Locations of sediment cores MD96-2081 (Peeters et al., 2004) and MD96-2077 (Bard and Rickaby, 2009) are also indicated. EMC eddies refer to East Madagascar Current eddies. The bathymetry according to a $1000 \mathrm{~m}$ step (the $1000 \mathrm{~m}$ contour is important in guiding the pathway of the AC and its retroflexion; De Ruijter et al., 1999) is also indicated (bathymetry from http://www.gebco.net/).

\subsection{Isotope analysis}

The core was sampled every $2-5 \mathrm{~cm}$ for $\delta^{18} \mathrm{O}$ of foraminifera. For each analysis, 4 to 6 specimens of planktonic G. ruber s. $s$. and benthic $P$. wuellerstorf foraminifera were picked from the $250-315 \mu \mathrm{m}$ size fraction. Analyses were carried out by a coupled system Multiprep-Optima of the mark Micromass at EPOC. The automated preparation system (Multiprep) transforms carbonate samples (50 to $100 \mu \mathrm{g}$ of calcium carbonate) to $\mathrm{CO}_{2}$ gas evolved by treatment with orthophosphoric acid at a constant temperature of $75^{\circ} \mathrm{C}$. The $\mathrm{CO}_{2}$ gas samples were then analysed by isotope mass spectrometry (Optima) in comparison with a calibrated reference gas 
to determine the isotopic ratio ${ }^{18} \mathrm{O} /{ }^{16} \mathrm{O}$ of the sample. For all stable oxygen isotope measurements a working standard (Burgbrohl $\mathrm{CO}_{2}$ gas) was used, which was calibrated against Vienna Pee Dee Belemnite (VPDB) by using the NBS 19 standard. Consequently, all $\delta^{18} \mathrm{O}$ data given here are relative to the VPDB standard. Analytical standard deviation is about $0.05 \% \circ( \pm 1 \sigma)$.

\section{$2.2 \mathrm{Mg} / \mathrm{Ca}$ analysis}

Core MD96-2048 was sampled every 2-5 cm for $\mathrm{Mg} / \mathrm{Ca}$ analysis of planktonic foraminifera. 25 specimens of $G$. ruber s. $s$. were picked within the $250-315 \mu \mathrm{m}$ size fraction for trace element analyses. Shells were cleaned to eliminate contamination from clays and organic matter based on the procedure of Barker et al. (2003). A Varian Vista Pro Inductively Coupled Plasma Optical Emission Spectrometer (ICP-OES) was used for magnesium and calcium analyses following the procedure established at LSCE (De Villiers et al., 2002). Reproducibility obtained from G. ruber s. s. samples was better than $4 \%( \pm 1 \sigma$, pooled RSD). For $\mathrm{Mg} / \mathrm{Ca}$ ratios determined with a standard solution of $\mathrm{Mg} / \mathrm{Ca}(5.23$ $\mathrm{mmol} / \mathrm{mol})$, analytical precision was $0.5 \%( \pm 1 \sigma, \mathrm{RSD})$. All the analyses were performed at LSCE, which participated in an inter-calibration exercise (Greaves et al., 2008). Measured $\mathrm{Mg} / \mathrm{Ca}$ ratios were converted into temperature values applying the equation established by Anand et al. (2003) yielding a precision of $1.2^{\circ} \mathrm{C}$.

\subsection{Alkenone and GDGT analyses}

Core MD96-2048 was sampled every 5-10 cm for long-chain alkenones and glycerol dialkyl glycerol tetraethers (GDGTs) analyses. Freeze-dried and grounded sediments were extracted with a Dionex Accelerated Solvent Extractor (ASE) using a 9:1 (v/v) mixture of dichloromethane and methanol at NIOZ. After extraction, a known amount $(1 \mu \mathrm{g})$ of $\mathrm{C}_{46}$ GDGT internal standard was added to the total extracts, which were further separated into three fractions by $\mathrm{Al}_{2} \mathrm{O}_{3}$ column chromatography using hexane/DCM (9:1, v/v), hexane/DCM (1:1, v/v) and DCM/MeOH (1:1, v/v) as subsequent eluents. A known amount of an internal standard, a deuterated ante-iso $\mathrm{C}_{22}$ alkane, was added to the alkenone fraction (hexane:DCM, 1:1, v/v) for quantification. The alkenone fraction (hexane/DCM, 1:1, v/v) was analysed by gas chromatography on a Agilent 6890 . The $U_{37}^{\mathrm{K}^{\prime}}$ index was calculated as defined by Prahl and Wakeham (1987). The $U_{37}^{\mathrm{K}^{\prime}}$ values were converted into temperature values applying the culture calibration by Prahl et al. (1988). The global core-top calibration $\left(60^{\circ} \mathrm{S}-60^{\circ} \mathrm{N}\right)$ based on 370 sites in the Atlantic, Indian and Pacific oceans has a precision of $1.5^{\circ} \mathrm{C}$ (Müller et al., 1998). The analytical precision of the method is about $0.3^{\circ} \mathrm{C}$.

The polar fraction (DCM/MeOH, 1:1, v/v), containing GDGTs, was analysed using a high-performance liquid chro- matography/atmospheric pressure chemical ionization-mass spectrometry. GDGTs were detected by single ion monitoring of their $(\mathrm{M}+\mathrm{H})^{+}$ions and quantification of the GDGT compounds was achieved by integrating the peak areas (Schouten et al., 2007) and using the internal standard $\left(\mathrm{C}_{46}\right.$ GDGT). The $\mathrm{TEX}_{86}^{\mathrm{H}}$ ratio was calculated as defined by Kim et al. (2010) and the $\mathrm{TEX}_{86}^{\mathrm{H}}$ values were converted into temperature using the calibration of Kim et al. (2010) yielding a precision of $2.5^{\circ} \mathrm{C}$. The analytical precision of the method is about $0.2^{\circ} \mathrm{C}$. The Branched and Isoprenoid Tetraether (BIT) index was calculated as defined by Hopmans et al. (2004).

\section{$2.4 \delta^{18} \mathrm{O}_{\mathrm{sw}}$ reconstruction (proxy of SSS)}

For the sea surface salinity (SSS) reconstruction, we followed the method developed by Duplessy et al. (1991) which leans on the double influence of surface temperature and the $\delta^{18} \mathrm{O}_{\text {sw }}$ isotopic composition of seawater on the isotopic values of the planktonic foraminifera (G. ruber s. s.). The isotopic temperature signals $(\mathrm{Mg} / \mathrm{Ca}-\mathrm{SST})$ are subtracted from the planktonic $\delta^{18} \mathrm{O}$ record (G. ruber s. $\left.s.\right)$. The residual signal can be interpreted in terms of past $\delta^{18} \mathrm{O}_{\mathrm{sw}}$ variations (linked to SSS variations). An additional correction, linked to variation effect of continental ice (due to glacialinterglacial changes) has been applied to obtain the final $\Delta \delta^{18} \mathrm{O}_{\mathrm{sw}}$ signal (Bintanja et al., 2005). Uncertainties of $\Delta \delta^{18} \mathrm{O}_{\text {sw }}$ estimates were obtained with an error propagation calculation (errors of $\mathrm{Mg} / \mathrm{Ca}-\mathrm{SST}\left(1.2^{\circ} \mathrm{C}\right)$ and planktonic $\delta^{18} \mathrm{O}$ measurements $(0.05 \%$ ) using the formula of Press et al. (1990). The overall uncertainty of $\Delta \delta^{18} \mathrm{O}_{\mathrm{sw}}$ estimates is $0.26 \%$ o $( \pm 1 \sigma)$.

\subsection{Spectral estimates}

For spectral estimates, the proxy records are linearly interpolated to a uniform spacing of $0.5 \mathrm{kyr}$ (see Supplement). The power spectral density, coherence and phase are estimated using a smoothed periodogram (Bloomfield, 1976). Before the analysis, a split cosine bell taper is applied to $10 \%$ of the data at the beginning and end of the series. To estimate the significance of the power spectral density, the spectrum background is estimated by fitting an analytical red noise spectrum to the median-smoothed spectrum estimate (Mann and Lees, 1996). The confidence intervals are calculated under the assumption that the spectral estimates are chi-square distributed (Percival and Walden, 1993). The degrees of freedom of the spectral estimate are 8 for the power spectral density calculation and 19 for the phase and coherency calculation. Our statistical procedure of estimating the significance of the sample coherence and the confidence intervals of the phase estimate largely follows Huybers and Denton (2008). To estimate the significance of the coherence, we use a Monte Carlo procedure to estimate the $95 \%$ significance level. Therefore, one of the two time-series is replaced by a red-noise process using the estimated lag-1 
auto-covariance. The coherence is estimated 10000 times on the surrogate time series. The uncertainty in the phase estimate is also estimated using a Monte Carlo procedure. Using white noise realizations, a signal according to the degree of coherence estimated from the data is generated. Here, the bias-corrected coherence estimate is used (Amos and Koopmans, 1963). The algorithm is repeated 10000 times to estimate the $95 \%$ confidence intervals for the phase estimate.

\section{Results}

Characteristic glacial-interglacial changes in the down-core record of stable oxygen isotopic composition of the benthic foraminifer Planulina wuellerstorfi $\left(\delta^{18} \mathrm{O}_{\text {benthic }}\right.$, Fig. 2a) served as control points for the age model tuned to the LR04 stack (Lisiecki and Raymo, 2005) (Fig. S1 in the Supplement), and allowed the identification of eight terminations. The age model of Lisiecki and Raymo (2005) constrains ages by aligning variations in the benthic foraminifera $\delta^{18} \mathrm{O}$ record with variations in the orbital parameters. It has been criticised that this approach precludes an objective evaluation of the orbital influence on glacial timing (Huybers, 2007). We, therefore, established an additional age model not relying upon orbital assumptions, by tuning the benthic $\delta^{18} \mathrm{O}$ record to the depth-derived age model (called H07: Huybers, 2007) (Fig. S1 in the Supplement). In general, the H07-based age model strongly resembles the LR04-based one. However, both age models deviate from each other for the time interval between MIS 7 and MIS 9.

We applied three independent inorganic and organic paleothermometers to reconstruct Agulhas current SST changes: $\mathrm{Mg} / \mathrm{Ca}$ ratios of the surface-dwelling planktonic foraminifer Globigerinoides ruber sensu stricto (De Villiers et al., 2002; Anand et al., 2003), alkenone unsaturation index $\left(U_{37}^{\mathrm{K}^{\prime}}\right)$ from haptophyte algae (Prahl and Wakeham, 1987), and the tetraether index $\left(\mathrm{TEX}_{86}^{\mathrm{H}}\right)$ of Thaumarchaeota (Schouten et al., 2002; Kim et al., 2010). Measuring three independent proxies is important to crosscheck temperature variations (Schouten et al., 2002; Kim et al., 2010). All three records are strongly related to each other $(R>0.5, p<0.01)$ and exhibit typical glacial-interglacial patterns (Fig. 3a). As each proxy has some uncertainty related to the calibration, non-temperature influences and lateral advection, the three records were averaged into a single SST stack (Figs. 2c and 3). Some studies have reported a seasonal bias on $\mathrm{TEX}_{86}^{\mathrm{H}}$ or $U_{37}^{\mathrm{K}^{\prime}}$ records; however, this is likely not the case in the Mozambique Channel region. Although modern sediments have not been studied exactly at the site of MD96-2048, a nearby sediment trap study $\left(16.8^{\circ} \mathrm{S}, 40.8^{\circ} \mathrm{E} ; 2250 \mathrm{~m}\right.$ water depth) (Fallet et al., 2010) provided some insights into the application of these proxies in the Mozambique Channel, located upstream of site MD96-2048. At the Mozambique Channel sediment trap site, mean annual SST is $27.6^{\circ} \mathrm{C}$, as measured by satellite remote sensing. The organic proxies

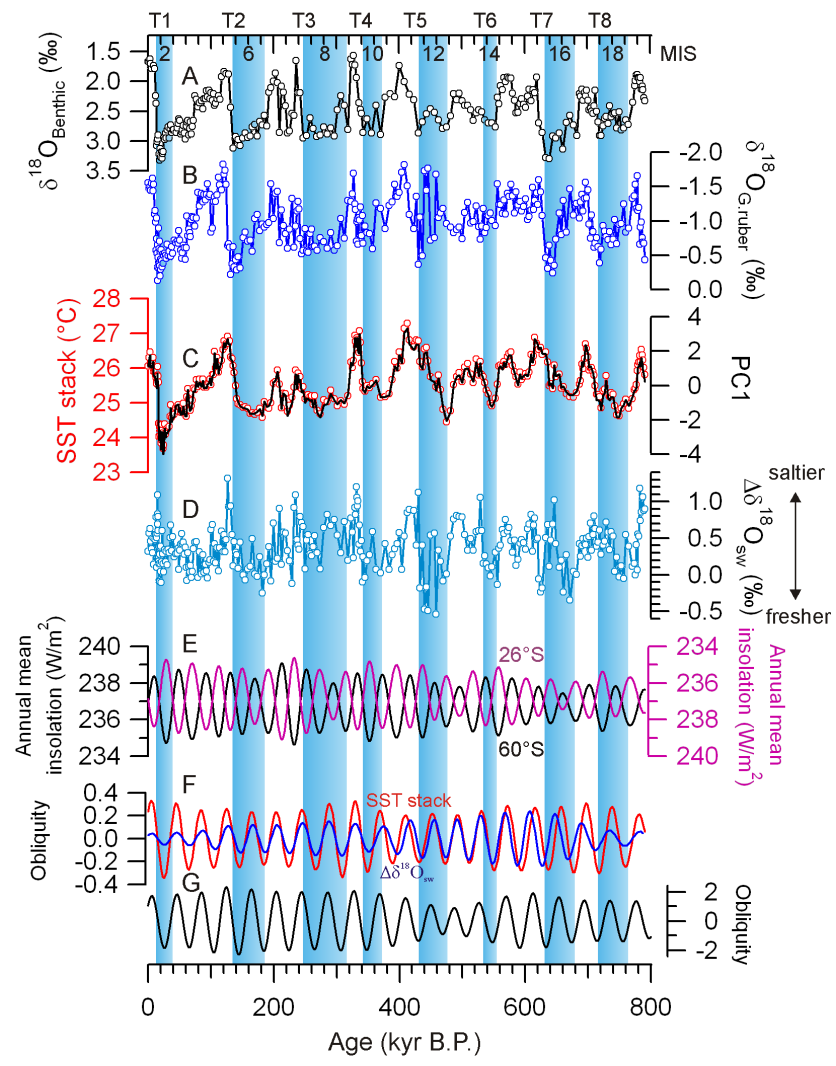

Fig. 2. Comparisons of MD96-2048 records with insolation and Antarctic climate record. (A) $\delta^{18} \mathrm{O}$ of benthic foraminifer P. wuellerstorfi, (B) $\delta^{18} \mathrm{O}$ of planktic foraminifer G. ruber, (C) stacked record of $\mathrm{Mg} / \mathrm{Ca}, U_{37}^{\mathrm{K}^{\prime}}$, and $\mathrm{TEX}_{86}^{\mathrm{H}}$ SSTs (red line) and first order of Principal Component (PC1, black line) derived from EOF analysis, (D) reconstructed $\Delta \delta^{18} \mathrm{O}_{\mathrm{sw}}$ (a proxy of regional sea surface salinity), (E) annual mean insolation at $60^{\circ} \mathrm{S}$ or $60^{\circ} \mathrm{N}$ (black) and $26^{\circ} \mathrm{S}$ (purple) calculated according to Berger and Loutre (1991), (F) obliquity components (frequency 1/41 000; bandwidth: 5e-06) of SST stack (red) and $\Delta \delta^{18} \mathrm{O}_{\mathrm{sw}}$ (blue) and (G) obliquity components (frequency 1/41 000; bandwidth: 5e-06) of atmospheric temperatures of EPICA Dome Concordia (EDC), Antarctica (Jouzel et al., 2007). $T$ indicates terminations and numbers indicate marine isotopic stages (MIS).

were found to reflect mean annual SST, but seasonal variability was not reflected in either $\mathrm{TEX} \mathrm{H}_{86}^{\mathrm{H}}$ or $U_{37}^{\mathrm{K}^{\prime}}$ records or in fluxes of thaumarchaeols or alkenones.

Before stacking, $U_{37}^{\mathrm{K}^{\prime}}$ and $\mathrm{TEX}_{86}^{\mathrm{H}}$ signals were linearly interpolated to the same time resolution as the $\mathrm{Mg} / \mathrm{Ca}$ signal, which is the SST dataset with the highest time resolution. It is reasonable to assume that the uncertainties are independent between the proxy types. Therefore, the stack is a more accurate temperature reconstruction than the usual interpretation of single temperature proxy records. To examine whether the SST stack is representative of coherent down-core temporal variation, we applied Empirical Orthogonal Function (EOF) analysis (Von Storch and Zwiers, 1999) on the three 


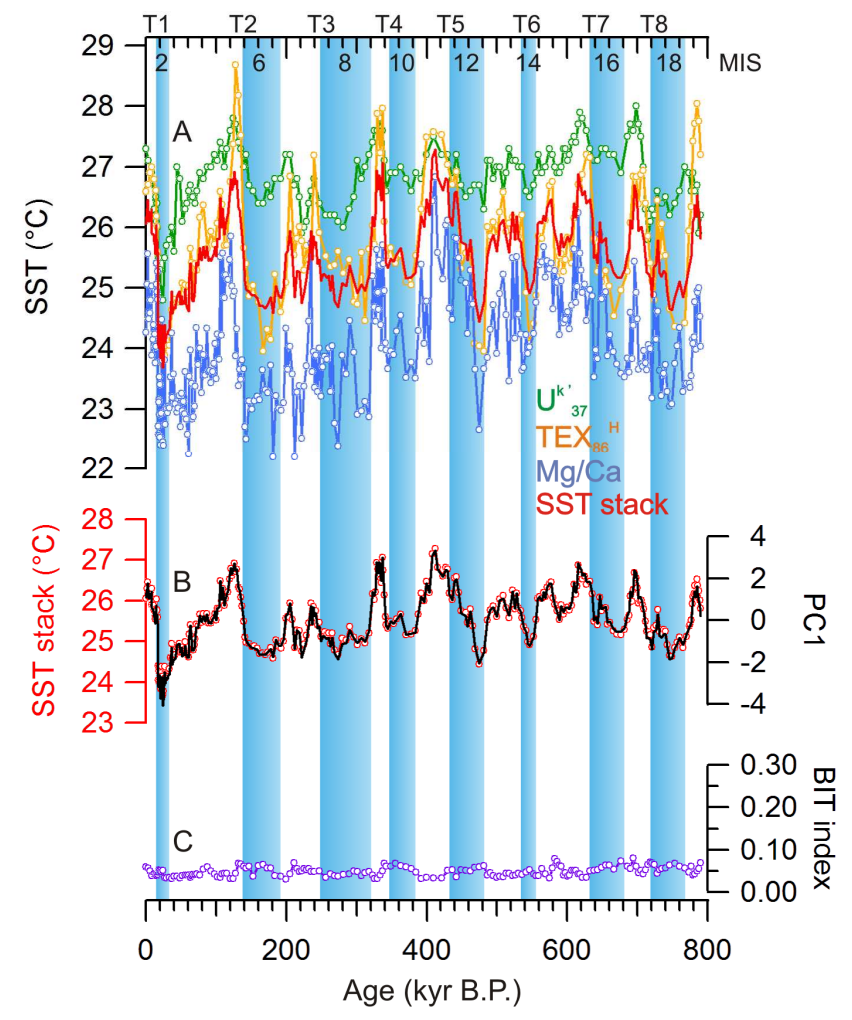

Fig. 3. Comparison of SST records from core MD96-2048 and BIT index. (A) $U_{37}^{\mathrm{K}^{\prime}}$ (green line), $\mathrm{TEX}_{86}^{\mathrm{H}}$ (orange line), $\mathrm{Mg} / \mathrm{Ca}$ (blue line), and the SST stack (red line). (B) Comparison of the SST stack (red line) with PC1. (C) BIT index values (purple line). $T$ indicates terminations and numbers indicate marine isotopic stages (MIS).

SST records (Fig. 3). An almost identical temporal variation of the first Principal Component (PC1, 74\% variance) and the SST stack $(R>0.99)$ confirms that this record represents the common temporal variation of the three individual SST records. In parallel, we constructed past $\Delta \delta^{18} \mathrm{O}_{\mathrm{sw}}$ (Fig. 2d), by combining the $\mathrm{Mg} / \mathrm{Ca}$ SST estimates with the $\delta^{18} \mathrm{O}$ values of G. ruber (Figs. 2b and S2 in the Supplement) and removing the influence of continental ice volume on global $\delta^{18} \mathrm{O}_{\mathrm{sw}}$.

The long-term, mean-annual hydrographic data suggest that northward-flowing, cool, upwelled waters have a weak influence at our core site (Fig. 4). The Branched and Isoprenoid Tetraether (BIT) Index (Hopmans et al., 2004) provides a method to assess the relative amount of soil organic matter input. In core MD96-2048, BIT values are extremely low $(<0.1$, Fig. $3 \mathrm{c})$ indicating that the isoprenoid GDGTs have a predominantly marine source throughout the length of the record. Thus, an influence of fluvial input of soilderived GDGTs at our core site can be excluded. In addition, pollen concentration (Dupont et al., 2011) obtained from this sediment core is low. Together, this suggests that the relative amount of terrestrial soil material in the studied core is very low. This indicates that core MD96-2048 mainly reflects changes in the upstream dynamics of the Agulhas

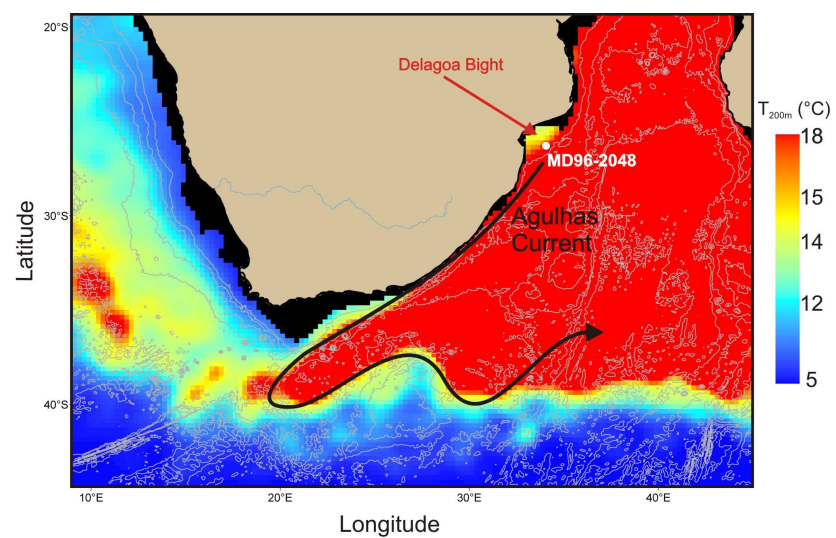

Fig. 4. Ocean temperature at $200 \mathrm{~m}$ depth in the Agulhas current region (long-term annual means (years 1900-1992) from NODC WOA94 data provided by the NOAA/OAR/ESRL PSD, Boulder, Colorado, USA, from their web site (http://www.esrl.noaa. gov/psd/; the bathymetry is also indicated with a $1000 \mathrm{~m}$ step: http://www.gebco.net/). The colour histogram was equalized to reinforce the vision of the temperature values which are close and give more contrast to the area where gradients in temperature are strong. Low temperature values are clearly observed in the Delagoa Bight and are probably indicative of the trapped lee eddy (Lutjeharms and da Silva, 1988). However, our core site seems preserved from the effect of this eddy and from upwelled waters flowing northward.

current rather than changes in coastal waters. Nonetheless, periodical interaction with the cold shelf waters and shelf cyclones cannot be completely excluded.

\section{Discussion}

\subsection{Orbital forcing of Agulhas current system records}

\subsubsection{Upstream Agulhas current}

The SST stack and the $\Delta \delta^{18} \mathrm{O}_{\mathrm{sw}}$ record display clear glacialinterglacial patterns (Fig. 2c-d) and spectral analysis revealed a strong signal in both 100-kyr (glacial-interglacial) and 41-kyr (obliquity) periodicities (Fig. 5a-b). The origin of the 100-kyr cycle could be linked to eccentricity forcing, to internally-driven climate feedbacks imparting some eccentricity influence (Lisiecki, 2010), or, alternatively, 100-kyr cycles can result from quantized bundles of 41-kyr obliquity cycles (Huybers and Wunsch, 2005). However, the 23kyr and 19-kyr (precession) signals, which are modulated by eccentricity, are weak in our records (Fig. 5), suggesting that eccentricity forcing plays no significant role at our site. While the amplitude of the precession signal might be slightly damped by the limited sampling resolution of the $U_{37}^{\mathrm{K}^{\prime}}$ and $\mathrm{TEX}_{86}^{\mathrm{H}}$ records (mean time step of 4.5-kyr), this cannot explain the small precession amplitude observed (Fig. S4 in the Supplement). Further, a similar result is found when analysing the $\mathrm{Mg} / \mathrm{Ca}$ SST record which has a higher 

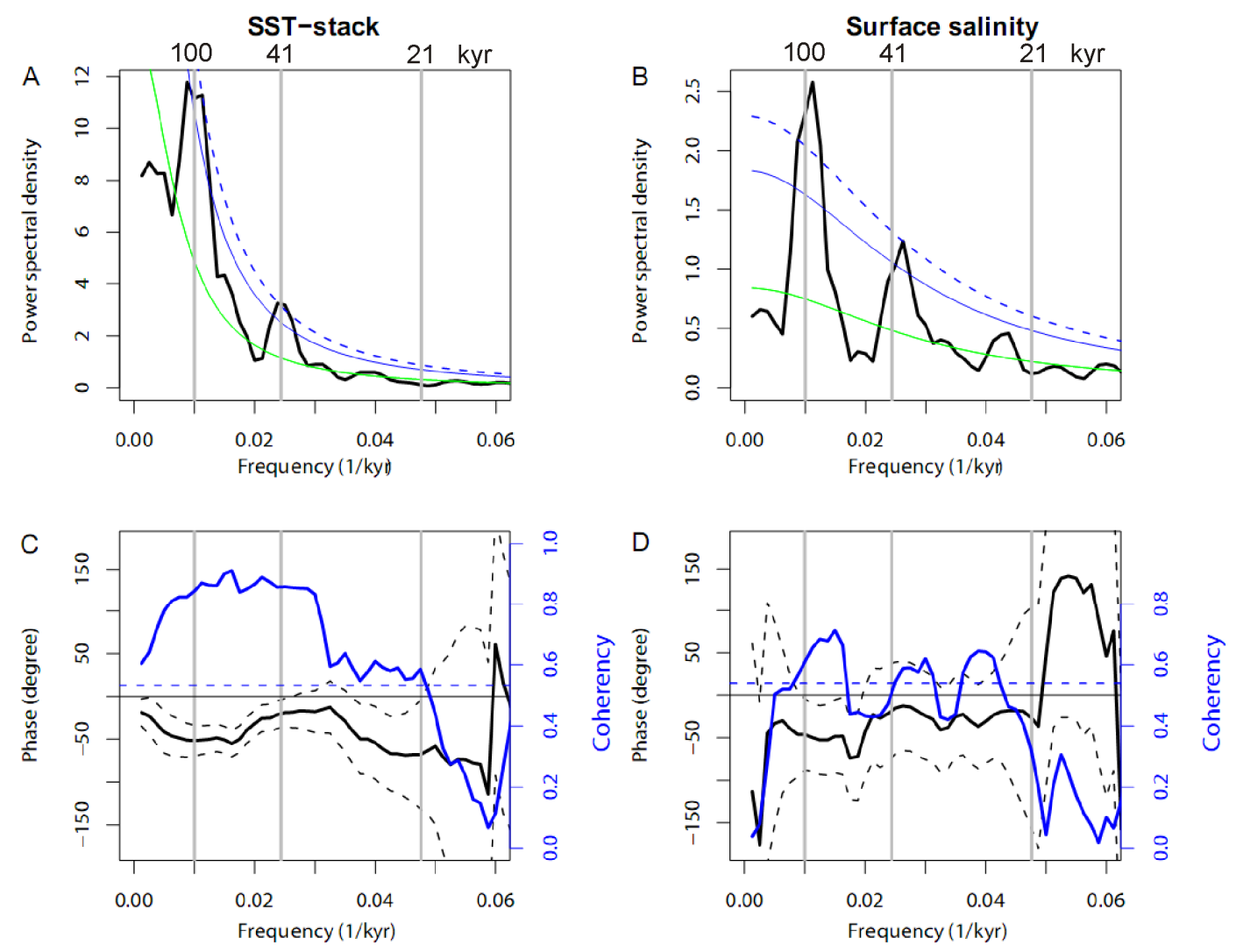

Fig. 5. Frequency spectra for Agulhas proxies (SST and SSS) and their coherence and phase relationships relative to global ice volume $\left(\delta^{18} \mathrm{O}_{\text {benthic }}\right)$. (A) Power spectral density of SST (black). A red noise background spectrum (green) and $95 \%$ (blue continuous) and $99 \%$ (blue dashed) confidence levels, relative to the red-noise background are given. (B) The same as in (A) but for SSS. (C) coherence (blue)

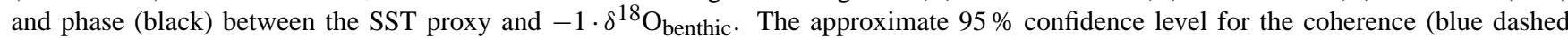
line) and the $95 \%$ confidence interval for phase (black dashed line) are given. (D) The same as in (C) but for the SSS and $-1 \cdot \delta^{18} \mathrm{O}_{\text {benthic }}$ relationship. A negative phase indicates that the Agulhas records are leading $-1 \cdot \delta^{18} \mathrm{O}_{\text {benthic }}$. The orbital frequencies $1 / 100 \mathrm{kyr}, 1 / 41 \mathrm{kyr}$ and $1 / 21 \mathrm{kyr}$ are marked with vertical grey lines.

sampling rate (mean time step of 2.5-kyr) record separately (Fig. S4 in the Supplement).

Interestingly, over the last $800 \mathrm{kyr}$, obliquity signals of the SST stack and the $\Delta \delta^{18} \mathrm{O}_{\mathrm{sw}}$ records (Fig. 2f) are nearly in phase with changes in high-latitude annual mean insolation (Fig. 2e), as well as with the obliquity component of Antarctic temperatures (Jouzel et al., 2007) (Fig. 2g), rather than with any local insolation index at $26^{\circ} \mathrm{S}$ (Berger and Loutre, 1991) (Fig. 2e). Regardless of whether the statistical analysis is performed using an alternative age model (Fig. S5 in the Supplement), or with the individual SST records (Fig. S6 in the Supplement), the important finding remains that all records vary in phase with changes in high-latitude obliquity. This indicates that a strong influence of local insolation on our records can be excluded; a linear response to local insolation would be out of phase in the obliquity band with the Agulhas records and local seasonal responses, e.g., caused by local nonlinearities (Leapple and Lohmann, 2009), and would contain a strong precession component contrary to our observation in the Agulhas records. An important role of the latitudinal insolation gradient can also be excluded as it contains both obliquity and precession frequencies as a result of seasonal differences in orbital forcing (Davis and Brewer, 2009). In addition, the latitudinal insolation gradient has been suggested as the origin of obliquity periodicities evident in the deuterium excess record from the Vostok ice core in Antarctica (Vimeux et al., 1999). However, the deuterium excess record is out of phase in the obliquity band with the Agulhas records as well as with obliquity components of the Antarctic temperatures (Vimeux et al., 1999).

Changes in high latitude insolation driven by variations in obliquity could explain both the important 41 and $100 \mathrm{kyr}$ cycles in the Agulhas current system. A common physical mechanism related to high latitude forcing, i.e., the varying position of the Southern Hemisphere subtropical front (STF) along with shifts of the Southern Hemisphere westerlies, has been proposed for glacial-interglacial (Peeters et al., 2004; Bard and Rickaby, 2009), orbital obliquity (Peeters et al., 2004) and contemporary climate changes (Biastoch et al., 2009). Interestingly, Antarctic temperature records 
Table 1. Phase and coherence between Agulhas surface proxies and $-1 \cdot \delta^{18} \mathrm{O}$ benthic. A negative phase indicates that the Agulhas surface records are leading $\delta^{18} \mathrm{O}$ benthic. In addition, phase and coherence between Antarctic temperature records and Agulhas SST stack record were calculated. A negative phase indicates that Agulhas SST stack is lagging Antarctic ice core records. Note that phase and coherence between the Vostok temperature record (Suwa and Bender, 2008) and Agulhas SST stack were calculated for an overlapping period (i.e., 0-411 kyr BP).

\begin{tabular}{lrrrr}
\hline Proxy & Frequency & Phase & $\begin{array}{r}95 \% \\
\text { confidence } \\
\text { interval }\end{array}$ & Coherence \\
& & & & \\
\hline SST stack & $100 \mathrm{ky}$ band & $-14.4 \mathrm{kyr}$ & $\pm 5.0 \mathrm{kyr}$ & 0.85 \\
& $41 \mathrm{ky}$ band & $-2.2 \mathrm{kyr}$ & $\pm 1.9 \mathrm{kyr}$ & 0.86 \\
& $21 \mathrm{ky}$ band & $-4.0 \mathrm{kyr}$ & $\pm 3.7 \mathrm{kyr}$ & 0.59 \\
\hline$\Delta \delta^{18} \mathrm{O}_{\mathrm{SW}}$ & $100 \mathrm{ky}$ band & $-12.8 \mathrm{kyr}$ & $\pm 11.6 \mathrm{kyr}$ & 0.61 \\
& $41 \mathrm{ky}$ band & $-1.7 \mathrm{kyr}$ & $\pm 6.1 \mathrm{kyr}$ & 0.54 \\
& $21 \mathrm{ky}$ band & $-1.5 \mathrm{kyr}$ & $\pm 7.5 \mathrm{kyr}$ & $0.33^{*}$ \\
\hline EDC3 & $100 \mathrm{ky}$ band & $-9.9 \mathrm{kyr}$ & $\pm 4.9 \mathrm{kyr}$ & 0.85 \\
$($ EDC3 & $41 \mathrm{ky}$ band & $-1.1 \mathrm{kyr}$ & $\pm 1.9 \mathrm{kyr}$ & 0.86 \\
chronology $)$ & $21 \mathrm{ky}$ band & $-1.4 \mathrm{kyr}$ & $\pm 5.4 \mathrm{kyr}$ & $0.37^{*}$ \\
\hline Vostok & $100 \mathrm{ky}$ band & $-4.6 \mathrm{kyr}$ & $\pm 4.8 \mathrm{kyr}$ & 0.83 \\
$\left(\mathrm{O}_{2} / \mathrm{N}_{2}\right.$ & $41 \mathrm{ky}$ band & $1.9 \mathrm{kyr}$ & $\pm 2.1 \mathrm{kyr}$ & 0.82 \\
chronology $)$ & $21 \mathrm{ky}$ band & $0.7 \mathrm{kyr}$ & $\pm 2.8 \mathrm{kyr}$ & 0.58 \\
\hline
\end{tabular}

* indicate that the coherence is not significant $(p=0.05)$.

(Jouzel et al., 2007) also exhibit a strong obliquity component (Fig. 2g). Consequently, the in-phase relationship of the obliquity component of Antarctic temperature (Jouzel et al., 2007) and the SST and SSS of the Agulhas current (Table 1) confirms that the variability in Agulhas current is strongly coupled to high latitude Southern Hemisphere climate forcing. Poleward shifts of the STF modify recirculation in the Indian subtropical gyre and would lead to the local increase in SST and SSS of the Agulhas current. The recirculation is the main mechanism to feed the Agulhas current (Stramma and Lutjeharms, 1997). We proposed that a STC southward allow recirculation of warmer waters in the Agulhas current even if at the same time the leakage of warm water out of the Indian Ocean, which is a small amount of $2-15 \mathrm{~Sv}$ (Richardson, 2007) compared to the mean transport of $70 \mathrm{~Sv}$ by the Agulhas current (Bryden et al., 2005), was simultaneously increased (Fig. 6c). Recent observations (Alory et al., 2007) and modelling results (Biastoch et al., 2009) have also shown warming/salinification tendencies of the southwest Indian Ocean in response to a poleward migration of the STF. Nonetheless, these modelling exercises are not in accordance with a new climate equilibrium experiment by Sijp and England (2009).

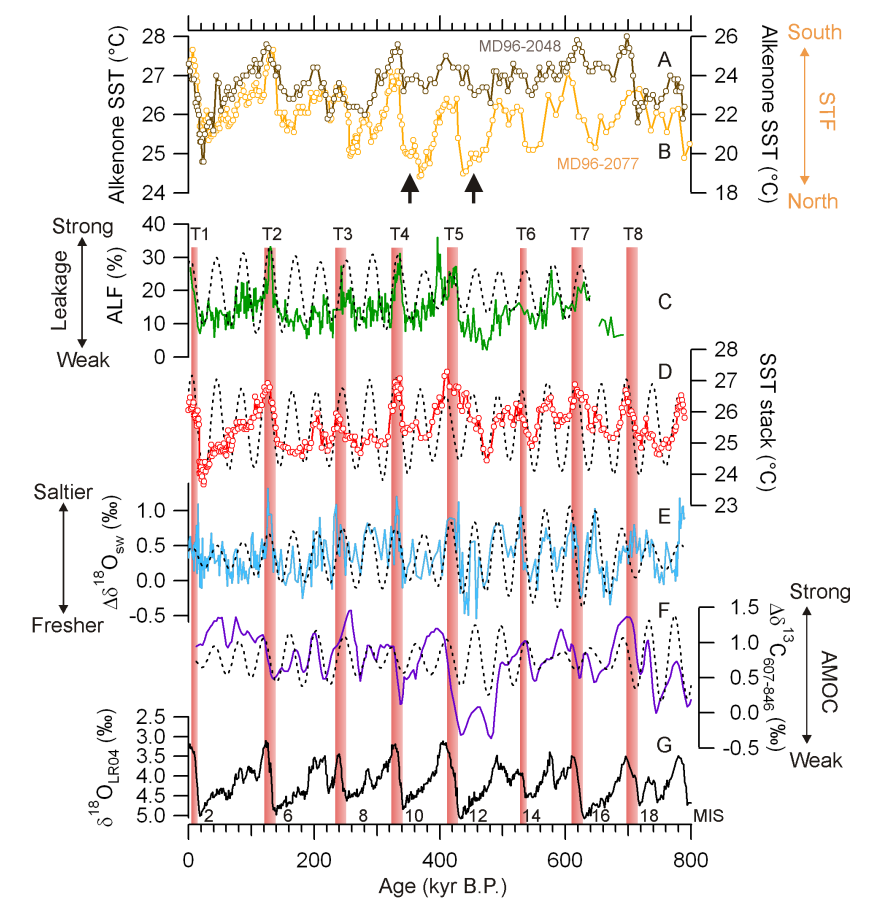

Fig. 6. Relationship between the subtropical front (STF) migration, the Agulhas current strength, the transfer of heat and salt, and the ventilation strength of the AMOC. (A) $U_{37}^{\mathrm{K}^{\prime}}$ SST record at site MD96-2048. Warmer glacial SSTs are observed in our record when the STF - in (B) - reaches its northern most position (black arrows). (B) $U_{37}^{\mathrm{K}^{\prime}} \mathrm{SST}$ record of MD96-2077, which was used as a proxy of STF migration (Bard and Rickaby, 2009). (C) Agulhas leakage fauna (ALF) record from core MD96-2081, a foraminiferal proxy of the Agulhas leakage (Peeters et al., 2004). Note that a new age model for core MD96-2081 was built based on the correlation between the $\delta^{18} \mathrm{O}$ of the benthic foraminifer $P$. wuellerstorf $i$ and the LR04 stack (Lisiecki and Raymo, 2005) to allow the comparison with our dataset. (D) Stacked record of $\mathrm{Mg} / \mathrm{Ca}, U_{37}^{\mathrm{K}^{\prime}}$, and $\mathrm{TEX}_{86}^{\mathrm{H}}$ SSTs at site MD96-2048. (E) Reconstructed $\Delta \delta^{18} \mathrm{O}_{\text {sw }}$ (a proxy of regional sea surface salinity) at site MD96-2048. (F) $\delta^{13} \mathrm{C}$ gradient between the Atlantic (site 607) and the Pacific (site 846) oceans as a proxy for the ventilation strength of the AMOC (Bard and Rickaby, 2009). For (C)-(F), black dash lines indicate the obliquity components (frequency 1/41 000; bandwidth: $5 \mathrm{e}-06$ ). (G) $\delta^{18} \mathrm{O}$ of LR04 stack (Lisiecki and Raymo, 2005). $T$ indicates terminations and numbers indicate marine isotopic stages (MIS).

\subsubsection{Agulhas transfer}

Our study provides a unique record of changes of surface hydrological parameters in the upstream region of the Agulhas current over the last 800-kyr. This allows us to investigate the potential relationship between the physical-chemical nature of upstream Agulhas current waters and the dynamical transfer (Agulhas leakage) further south. Abundance changes in Agulhas leakage fauna (ALF), a foraminiferal proxy of Agulhas leakage in the Cape basin (Peeters et al., 2004), also 
exhibit strong obliquity and $100 \mathrm{kyr}$ cycles (Peeters et al., 2004) (Fig. 6c). Our records and that of the ALF compare well, suggesting an important interconnection between the upstream and downstream region of the Agulhas current (Fig. 6).

However, whereas the ALF record still shows a weak signal in the precession band, this orbital periodicity is negligible in our SST and SSS records (Figs. 5-S7, Supplement). Various hypotheses can be put forward to explain this apparent discrepancy in patterns of orbitaly-related periodicities between the two regions:

1. Peeters et al. (2004) argue for a link of the Agulhas leakage with the low-latitude monsoon in order to explain the presence of precession signals in their ALF record. The proposed mechanism involves a modulation of the Agulhas current sources by current eddies in the Mozambique channel and East Madagascar upstream regions, that can propagate downstream into the retroflection and trigger Agulhas rings (Schouten et al., 2002). Considering the location of our study site in the precursor region of the Agulhas current, it would record the passage of these eddies which influence the physical properties of the water masses (Fallet et al., 2011). However, no such procession signal is found in our SST and SSS records. In addition, in contrast to the pattern seen in the ALF proxy-record (Peeters et al., 2004), changes in paleo-monsoon strength are not phased with changes in the Northern Hemisphere summer insolation (Clemens et al., 2010; Caley et al., 2011). This suggests that the increased strength of the Indo-Asian monsoon cannot fully explain the timing of the precession signal recorded in the ALF record.

2. The second hypothesis calls for a weak precession signal in the proxy record of STF latitudinal migrations (Peeters et al., 2004). Considering the importance of the recirculation mechanism in controlling hydrographic parameters at our core site (via STF latitudinal migrations), the lack of a precession signal in the SST and SSS records of the Agulhas current upstream region is, therefore, at odds with this process. An explanation for this apparent contradiction might be sought in both the amplitude of the latitudinal migration of the STF and the distance separating the upstream Agulhas current region where our study site is located from the Agulhas leakage region. A weak migration of the STF, according to precession cycles, could affect the ALF $\left(\sim 35^{\circ} S\right)$ and explain the weak precession signal in the records of Peeters et al. (2004). However, the STF migration might not be important enough to allow strong changes in the recirculation and affect significantly the hydrographic parameters at our core site, ten degrees further to the north $\left(26^{\circ} \mathrm{S}\right)$. This suggests that the precession signal in the Agulhas leakage might be linked to a high-latitude climate forcing via Southern Hemisphere frontal changes (migration of the STF) rather than by low latitude climate forcing originating in the Indian Ocean.

3. The presence of a weak precession signal in the ALF proxy record (and its absence in the Agulhas current upstream region where our study core originates) might be related to the main oceanographic process at work on the continental margin off SW Africa, that is coastal upwelling. The so-called Benguela upwelling system extends from about $15^{\circ} \mathrm{S}$ to $35^{\circ} \mathrm{S}$ latitude (Shannon, 1985). The ALF proxy record was, therefore, extracted from a sediment core (ca. $35^{\circ} \mathrm{S}, 17^{\circ} \mathrm{E}$; Peeters et al., 2004) that is located in close vicinity to the southernmost cells and associated filamentous regime off the Cape of Good Hope (Lutjeharms and Meeuwis, 1987; Fig. 1), and is, therefore, likely to bear some essential elements of the dynamics of the Benguela upwelling process. One of these elements is a $23 \mathrm{kyr}$ period of wind strength as seen by Pichevin et al. (2005) in Benguela coastal upwelling records.

We ultimately propose that the Agulhas current system is mainly controlled by high latitude obliquity at orbital scale changes. Obliquity may drive an important part of the $100 \mathrm{kyr}$ cycles observed in the system, whereas the precession periodicity is lacking in the upstream system, its power is weak in the leakage record (Peeters et al., 2004) and could be related to processes at work in the SE Atlantic (i.e., the Benguela current/upwelling system).

\subsection{Migration of the Subtropical front, strength of the Agulhas current and Indian-Atlantic leakage}

Recently, it has been suggested that northward migrations of the STF modulated the severity of each glacial period (particularly during MIS 10 and 12) (Bard and Rickaby, 2009). The hypothesis that a northward-migrating STF would block the Agulhas current and, thus, affect water transport from the Indian Ocean to the South Atlantic is still under debate (De Ruijter et al., 1999; Rau et al., 2002; Bard and Rickaby, 2009; Zahn, 2009; Beal et al., 2011). For the exceptional MIS 12 (extreme northward position of the STF) (Bard and Rickaby, 2009), all records at site MD96-2048 show an early increase in SST, whereas the coldest SSTs are observed further south at ca. $33^{\circ} \mathrm{S}$ where core MD962077 is located (Figs. 1 and 6). This could suggest that the build-up of heat from the return flow of the Agulhas current is linked to the latitudinal contraction of subtropical gyres (Sijp and England, 2008). The MIS 12 configuration is exceptional compared with other glacial/interglacial periods for which our measurements indicate a decrease/increase in SST and SSS in the upstream Agulhas current region reflecting a northward/southward shift in the gyre (Alory et al., 2007). A comparison of our SST record with that of MD96-2077 also reveals stronger deviations during the glacial periods, 
especially MIS 10 and 12 (Fig. 6a-b). Increased glacial SSTs were recorded at site MD96-2048 when the STF reached its northern most position, which may be related to a build-up of heat from the return flow that could not escape to the Atlantic as for MIS 12. However, this pattern is only recorded in the SST record and not in $\mathrm{Mg} / \mathrm{Ca}$ and $\mathrm{TEX}_{86}^{\mathrm{H}}$ SST signals (Fig. 3a). Instead, we argue that lateral fluxes, linked to the Agulhas current, could be stronger when Agulhas leakage was weaker at glacial/interglacial time scale (Supplement).

According to Beal et al. (2011), the main controls on Agulhas leakage are the latitude of maximum westerlies and the southward inertia of the Agulhas current. At glacialinterglacial cycles, if the wind pattern is fixed but its strength is reduced, a weaker Agulhas current would result in increased leakage and our results would be in good agreement with these modelling exercises (De Ruijter, 1982; Dijkstra and De Ruijter, 2001; Van Sebille et al., 2009). If the winds shift northward and weaken during glacial periods, a weaker Agulhas current could combine with a reduced leakage (Franzese et al., 2009). Our data contradict the hypothesis of Franzese et al. (2009) as we find that a stronger Agulhas current, associated with a wind pattern shifted northward during glacial periods, leads to reduced leakage (Fig. 6a-c). Even if our results are consistent with the theory, further research investigating the inertia of the Agulhas current under glacial-interglacial periods is necessary.

\subsection{Potential impact of Agulhas leakage on AMOC}

Our results show that changes in SST and SSS led variations in global ice volume (i.e., benthic $\delta^{18} \mathrm{O}$ value) on obliquity time-scales (Fig. $5 \mathrm{c}-\mathrm{d}$ ). The time-lags of benthic $\delta^{18} \mathrm{O}$ are $2.2 \mathrm{kyr}( \pm 1.9 \mathrm{kyr}, 95 \%$ confidence interval) for SST and $1.7 \mathrm{kyr}\left( \pm 6.1 \mathrm{kyr}, 95 \%\right.$ confidence interval) for $\Delta \delta^{18} \mathrm{O}_{\text {sw }}$ in the obliquity band (Table 1 ). The ALF variations also led benthic $\delta^{18} \mathrm{O}$ changes in the Cape basin (Peeters et al., 2004) (Fig. 6). Enhanced leakage of warmer and saltier Indian Ocean waters into the South Atlantic during the terminations, with potential influence on the AMOC (Weijer et al., 2001; 2002), therefore, occurred before major changes in global ice volume change. Recently, Lisiecki et al. (2008) showed that maxima in high northern latitude summer insolation (i.e., Milankovitch forcing) are associated with greater mid-depth Atlantic overturning in the obliquity band, but with less overturning in the precession band. This suggests that the AMOC is more strongly influenced by other factors than ice volume changes and summer insolation at high northern latitudes (Lisiecki et al., 2008) as suggested previously by the SPECMAP theory. Interestingly, Dickson et al. $(2009,2010)$ also showed that a stronger AMOC during MIS 11 inhibited significant ice-sheet build-up and prolonged the interglacial period at a time of high orbital obliquity. Our results suggest that changes in Agulhas leakage might, among other factors, modulate the efficiency of AMOC as a response to orbitalobliquity forcing. In order to test this hypothesis, we com- pared our records from the Agulhas current system with the foraminiferal benthic $\delta^{13} \mathrm{C}$ gradient between the Atlantic and the Pacific oceans used as a proxy of deep ocean ventilation (Bard and Rickaky, 2009) (Fig. 6f). Interestingly, periods of increased strength of the AMOC are synchronous with increased Agulhas leakage in the obliquity band (Fig. 6). In addition, all terminations over the last 800-kyr are characterised by both increased inter-ocean leakage and AMOC strength at a time of high orbital obliquity (Fig. 6).

Obliquity-driven glacial terminations during the late Pleistocene have previously been hypothesized (Huybers and Wunsch, 2005) and more recently supported by a speleothem record from the Northeast Atlantic region (Drysdale et al., 2009), showing the influence of obliquity and AMOC variations on Termination 2. However, feedback mechanisms that amplified the initial obliquity forcing have not been elucidated yet. AMOC responses to orbital forcing are also highly model-dependent, showing contradictory results (Yoshimori et al., 2001; Khodri et al., 2003). Our finding of obliquitydriven Agulhas current system sheds light on an important internal forcing of long-term AMOC responses to the interocean heat and salt exchange. We suggest that this obliquity signal is transmitted from the Southern Hemisphere to the Northern Hemisphere via AMOC changes. This could explain why AMOC variability is not solely dependent on ice volume and summer insolation at high northern latitudes (Lisiecki et al., 2008).

\section{Conclusions}

Sea surface temperature and salinity records from the upstream (precursor) region of the Agulhas current contain strong obliquity-driven 41-kyr and 100-kyr cycles over the last 800 kyr. Agulhas leakage records (Peeters et al., 2004) also contain a strong obliquity-driven $41-\mathrm{kyr}$ cycle in addition to an important $100-\mathrm{kyr}$ cycle and a weak precession signal, which is lacking in the upstream region. The weak precession periodicity, that is present in the planktic foraminiferal-based Agulhas leakage record, does not appear to be controlled by variability in the strength of the Indian monsoon, but more likely originates from the high latitude Southern Hemisphere and/or from the dynamics of the nearby Benguela upwelling system. This suggests that longterm Agulhas current system dynamics are mainly triggered by a high latitude rather than a tropical climate mechanism, i.e., by the varying position of the Southern Hemisphere STF and its associated westerlies.

The relationship between the strength of the Agulhas current, the effect of wind pattern shifts and their impact on the efficiency of the inter-ocean leakage requires further investigation. Our results, however, suggest that a stronger Agulhas current, associated with a northward shift of the wind system during glacial periods, lead to reduced leakage, in accordance with the theory. 
To trigger ice age terminations, important feedbacks need to be added to the direct effect of insolation changes on ice sheets. We argue that the important transfer of heat and salt via the Agulhas current, which affected the resumption of the AMOC and the initiation of interglacial conditions (Weijer et al., 2002; Knorr and Lohmann, 2003; Biastoch et al., 2008), is one of the main feedbacks. Fully coupled ocean-atmosphere models do not resolve the Agulhas leakage (Lohmann, 2003; Beal et al., 2011). Therefore, obliquity-induced variability of the Agulhas current system merits greater attention in global ocean and climate models used for predicting the future climate scenarios. Changes in this parameter might be of importance to predicting changes in the Agulhas current system in a changing climate, and to resolved Agulhas current dynamics and impacts on AMOC in paleoclimate simulations.

\section{Supplementary material related to this article is available online at: http://www.clim-past.net/7/1285/2011/ cp-7-1285-2011-supplement.pdf.}

Acknowledgements. The technical staffs at EPOC, LSCE and NIOZ are thanked for their contributions to sample preparation and measurements. All members of the PALEO group at EPOC, as well as E. Bard at CEREGE are acknowledged for their help, stimulating discussions and for comments on an early version of the manuscript. Core MD96-2048 was collected during the MOZAPHAR cruise of the RV Marion Dufresne, supported by the French agencies Ministère de l'Education Nationale de la Recherche et de la Technologie, Centre National de la Recherche Scientifique (CNRS), and Institut Paul Emile Victor (IPEV). Financial contribution from the CNRS INSU LEFE-EVE programme "MOMIES" is acknowledged. This paper is contribution 1841 of UMR5805 EPOC, University Bordeaux 1.

Edited by: M. Siddall

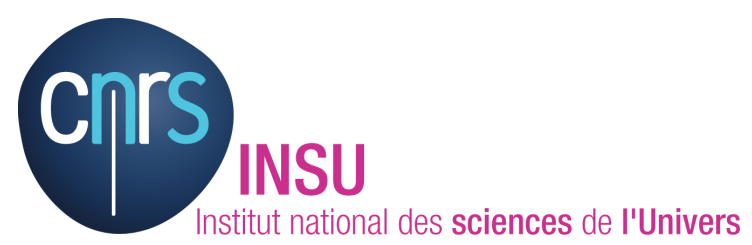

The publication of this article is financed by CNRS-INSU.

\section{References}

Alory, G., Wijffels, S., and Meyers, G.: Observed temperature trends in the Indian Ocean over 1960-1999 and associated mechanisms, Geophys. Res. Lett., 34, L02606, doi:10.1029/2006GL028044, 2007.

Amos, D. and Koopmans, L.: Tables of the distribution of the coefficient of coherence for stationary bivariate Gaussian processes, SCR-483, Sandia Corp, 1963.
Anand, P., Elderfield, H., and Conte, M. H.: Calibration of $\mathrm{Mg} / \mathrm{Ca}$ thermometry in planktonic foraminifera from a sediment trap time series, Paleoceanography, 18, 1050, doi:10.1029/2002PA000846, 2003.

Bard, E. and Rickaby, E. M.: Migration of the subtropical front as a modulator of glacial climate, Nature, 460, 380-383, 2009.

Barker, S., Greaves, M., and Elderfield, H.: A study of cleaning procedures used for foraminiferal $\mathrm{Mg} / \mathrm{Ca}$ paleothermometry, Geochem. Geophy. Geosy., 4, 21 pp., 2003.

Beal, L. M., De Ruijter, W. P. M., Biastoch, A., Zahn, R., and SCOR/WCRP/IAPSO Working Group 136: On the role of the Agulhas system in ocean circulation and climate, Nature, 472, 429-436, 2011.

Berger, A. and Loutre, M.: Insolation values for the climate of the last 10 million years, Quaternary Sci. Rev., 10, 297-317, 1991.

Biastoch, A., Boning, C. W., and Lutjeharms, J. R. E.: Agulhas leakage dynamics affects decadal variability in Atlantic overturning circulation, Nature, 456, 489-492, 2008.

Biastoch, A., Boning, C. W., Schwarzkopf, F. U., and Lutjeharms, J. R. E.: Increase in Agulhas leakage due to poleward shift of Southern Hemisphere westerlies, Nature, 462, 495-498, 2009.

Bintanja, R., Van de Wal, R., and Oerlemans, J.: Modelled atmospheric temperatures and global sea levels over the past million years, Nature, 437, 125-128, 2005.

Bloomfield, P.: Fourier analysis of time series: An introduction, Wiley, New York, 1976.

Bryden, H. L., Beal, L. M., and Duncan, L. M.: Structure and transport of the Agulhas Current and its temporal variability, J. Oceanogr., 61, 479-492, 2005.

Caley, T., Malaizé, B., Zaragosi, S., Rossignol, L., Bourget, J., Eynaud, F., Martinez, P., Giraudeau, J., Charlier, K., and EllouzZimmermann, N.: New Arabian Sea records help decipher orbital timing of Indo-Asian monsoon, Earth Planet. Sc. Lett., 433444, doi:10.1016/j.epsl.2011.06.019, 2011.

Clemens, S. C., Prell, W. L., and Sun, Y.: Orbital-scale timing and mechanisms driving Late Pleistocene Indo-Asian summer monsoons: Reinterpreting cave speleothem $\delta^{18} \mathrm{O}$, Paleoceanography, 25, PA4207, doi:10.1029/2010PA001926, 2010.

Davis, B. A. S. and Brewer, S.: Orbital forcing and role of the latitudinal insolation/temperature gradient, Clim. Dynam., 32, 143145, 2009.

De Ruijter, W.: Asymptotic analysis of the Agulhas and Brazil Current systems, J. Phys. Oceanogr., 12, 361-373, 1982.

De Ruijter, W. P. M., Biastoch, A., Drijfhout, S. S., Lutjeharms, J. R. E., Matano, R. P., Pichevin, T., van Leeuwen, P. J., and Weijer, W.: Indian-Atlantic inter-ocean exchange: dynamics, estimation and impact, J. Geophys. Res., 104, 20885-20911, 1999.

De Villiers, S., Greaves, M., and Elderfield, H.: An intensity ratio calibration method for the accurate detremination of $\mathrm{Mg} / \mathrm{Ca}$ and $\mathrm{Sr} / \mathrm{Ca}$ of marine carbonates by ICP-AES, Geochem. Geophy. Geosy., 3, 1001, doi:10.1029/2001GC000169, 2002.

Dickson, A. J., Beer, C. J., Dempsey, C., Maslin, M. A., Bendle, J. A., McClymont, E. L., and Pancost, R. D.: Oceanic forcing of the Marine Isotope Stage 11 interglacial, Nat. Geosci., 2, 428-433, 2009.

Dickson, A. J., Leng, M. J., Maslin, M. A., Sloane, H. J., Green, J., Bendle, J. A., McClymont, E. L., and Pancost, R. D.: Atlantic overturning circulation and Agulhas leakage influences on southeast Atlantic upper ocean hydrography dur- 
ing marine isotope stage 11, Paleoceanography, 25, PA3208, doi:10.1029/2009PA001830, 2010.

Dijkstra, H. A. and de Ruijter, W. P. M.: On the physics of the Agulhas: steady retroflection regimes, J. Phys. Oceanogr., 31, 2971-2985, 2001.

Drysdale, R. N., Hellstrom, J. C., Zanchetta, G., Fallick, A. E., Sánchez Goñi, M. F., Couchoud, I., McDonald, J., Maas, R., Lohmann, G., and Isola, I.: Evidence for obliquity forcing of Glacial termination II, Science, 325, 1527-1531, 2009.

Duplessy, J. C., Labeyrie, L., Juillet-Leclerc, A., Maitre, F., Duprat, J., and Sarnthein, M.: Surface salinity reconstruction of the North Atlantic Ocean during the last glacial maximum, Oceanol. Acta, 14, 311-324, 1991

Dupont, L. M., Caley, T., Kim, J.-H., Castaneda, I., Malaizé, B., and Giraudeau, J.: Glacial-interglacial vegetation dynamics in south eastern Africa depend on sea surface temperature variations in the west Indian Ocean, Clim. Past Discuss., 7, 22612296, doi:10.5194/cpd-7-2261-2011, 2011

Fallet, U., Brummer, G. J., Zinke, J., Vogels, S., and Ridderinkhof, H.: Contrasting seasonal fluxes of planktonic foraminifera and impacts on paleothermometry in the Mozambique Channel upstream of the Agulhas Current, Paleoceanography, 25, PA4223/1-PA4223/12, doi:10.1029/2010PA001942, 2010.

Fallet, U., Ullgren, J. E., Castañeda, I. S., van Aken, H. M., Schouten, S., Ridderinkhof, H., and Brummer, G.-J. A.: Contrasting variability in foraminiferal and organic paleotemperature proxies in sedimenting particles of the Mozambique Channel (SW Indian Ocean), Geochim. Cosmochim. Acta, 75, 5834 5848, doi:10.1016/j.gca.2011.08.009, 2011.

Franzese, A. M., Hemming, S. R., and Goldstein, S. L.: Use of strontium isotopes in detrital sediments to constrain the glacial position of the Agulhas Retroflection, Paleoceanography, 24, PA2217, doi:10.1029/2008PA001706, 2009.

Gordon, A. L.: The brawniest retroflection, Nature, 421, 904-905, 2003.

Greaves, M., Caillon, N., and Rebaubier, H., Bartoli, G., Bohaty, S., Cacho, I., Clarke, L., Cooper, M., Daunt, C., Delaney, M., deMenocal, P., Dutton, A., Eggins, S., Elderfield, H., Garbe-Schoenberg, D., Goddard, E., Green, D., Groeneveld, J., Hastings, D., Hathorne, E., Kimoto, K., Klinkhammer, G., Labeyrie, L., Lea, D.W., Marchitto, T., Martínez-Botí, M. A., and Mortyn, P. G., Ni, T., Nuernberg, D., Paradis, G., Pena, L., Quinn, T., Rosenthal, Y., Russell, A., Sagawa, T., Sosdian, S., Stott, L., Tachikawa, K., Tappa, E., Thunell, R., and Wilson, P. A.: Interlaboratory comparison study of calibration standards for foraminiferal $\mathrm{Mg} / \mathrm{Ca}$ thermometry, Geochem. Geophy. Geosy., 9, Q08010, doi:10.1029/2008GC001974, 2008.

Hopmans, E. C., Weijers, J. W. H., Schefuß, E., Herfort, L., Sinninghe Damste, J. S., and Schouten, S.: A novel proxy for terrestrial organic matter in sediments based on branched and isoprenoid tetraether lipids, Earth Planet. Sc. Lett., 224, 107-116, 2004

Huybers, P.: Glacial variability over the last two million years: an extended depth-derived agemodel, continuous obliquity pacing, and the Pleistocene progression, Quaternary Sci. Rev., 26, 37$55,2007$.

Huybers, P. and Denton, G.: Antarctic temperature at orbital timescales controlled by local summer duration, Nat. Geosci., 1, 787-792, 2008
Huybers, P. and Wunsch, C.: Obliquity pacing of the late Pleistocene glacial terminations, Nature, 434, 491-494, 2005.

Jouzel, J., Masson-Delmotte, V., Cattani, O., Dreyfus, G., Falourd, S., Hoffmann, G., Minster, B., Nouet, J., Barnola, J. M., Chappellaz, J., Fischer, H., Gallet, J. C., Johnsen, S., Leuenberger, M., Loulergue, L., Luethi, D., Oerter, H., Parrenin, F., Raisbeck, G., Raynaud, D., Schilt, S., Schwander, J., Selmo, E., Souchez, R., Spahni, R., Stauffer, B., Steffensen, J. P., Stenni, B., Stocker, T. F., Tison, J. L., Werner, M., and Wolff, E. W.: Orbital and Millennial Antarctic Climate Variability over the Past 800,000 Years, Science, 317, 793-796, 2007.

Khodri, M., Ramstein, G., Duplessy, J. C., Kageyama, M., Paillard, D., and Ganopolski, A.: Modelling the climate evolution from the last interglacial to the start of the last glaciation: The role of Arctic Ocean freshwater budget, Geophys. Res. Lett., 30, 1606, doi:10.1029/2003GL017108, 2003.

Kim, J. H., Meer, J. V. D., Schouten, S., Helmke, P., Willmot, V., Sangiorgi, F., Koç, N., Hopmans, E. C., and Sinninghe Damste, J. S.: New indices and calibrations derived from the distribution of crenarchaeal isoprenoid tetraether lipids: Implications for past sea surface temperature reconstructions, Geochim. Cosmochim. Acta, 74, 4639-4654, 2010.

Knorr, G. and Lohmann, G.: Southern Ocean origin for the resumption of Atlantic thermohaline circulation during deglaciation, $\mathrm{Na}$ ture, 424, 532-536, 2003.

Laepple, T. and Lohmann, G.: Seasonal cycle as template for climate variability on astronomical timescales, Paleoceanography, 24, PA4201, doi:10.1029/2008PA001674, 2009.

Lisiecki, L. E.: Links between eccentricity forcing and the 100,000year glacial cycle, Nat. Geosci. 3, 349-352, 2010.

Lisiecki, L. E. and Raymo, M. E.: A Pliocene-Pleistocene stack of 57 globally distributed benthic $\delta^{18} \mathrm{O}$ records, Paleoceanography, 20, PA1003, doi:10.1029/2004PA001071, 2005.

Lisiecki, L. E., Raymo, M. E., and Curry, W. B.: Atlantic overturning responses to Late Pleistocene climate forcings, Nature, 456, 85-88, doi:10.1038/nature07425, 2008.

Lohmann, G.: Atmospheric and oceanic freshwater transport during weak Atlantic overturning circulation, Tellus A, 55, 438-449, 2003.

Lutjeharms, J. R. E.: The Agulhas Current, Springer, 2006.

Lutjeharms, J. R. E. and Jorge da Silva, A.: The Delagoa Bight eddy, Deep-Sea Res., 35, 619-634, 1988.

Lutjeharms, J. R. E. and Meeuwis, J. M.: The extent and variability of the South East Atlantic upwelling, South Afr. J. Mar. Sci., 5, 51-62, 1987

Lutjeharms, J. R. E., Cooper, J., and Roberts, M.: Upwelling at the inshore edge of the Agulhas Current, Cont. Shelf Res., 20 , 737-761, 2000.

Machu, E., Lutjeharms, J. R. E., Webb, A. M., and van Aken, H. M.: First hydrographic evidence of the southeast Madagascar upwelling cell, Geophys. Res. Lett., 29, 2009, doi:10.1029/2002GL015381, 2002.

Mann, M. E. and Lees, J. M.: Robust estimation of background noise and signal detection in climatic time series, Climatic Change, 33, 409-445, 1996.

Martínez-Méndez, G., Zahn, R., Hall, I. R., Peeters, F. J. C., Pena, L. D., Cacho, I., and Negre, C.: Contrasting multiproxy reconstructions of surface ocean hydrography in the $\mathrm{Ag}$ ulhas Corridor and implications for the Agulhas Leakage dur- 
ing the last 345,000 years, Paleoceanography, 25, PA4227, doi:10.1029/2009PA001879, 2010.

Müller, P., Kirst, G., Ruhland, G., von Storch, I., and Rosell-Melé, A.: Calibration of the alkenone paleotemperature index based on core-tops from the eastern South Atlantic and the global ocean $\left(60^{\prime} \mathrm{N}-60^{\prime} \mathrm{S}\right)$, Geochim. Cosmochim. Acta, 62, 17571772, 1998.

Peeters, F., Acheson, R., Brummer, G. J. A., de Ruijter, W. P. M., Schneider, R. R., Ganssen, G. M., Ufkes, E., and Kroon, D.: Vigorous exchange between the Indian and Atlantic oceans at the end of the past five glacial periods, Nature, 430, 661-665, 2004.

Percival, D. B. and Walden, A. T.: Spectral analysis for physical applications: multitaper and conventional univariate techniques, Cambridge Uni. Press, Cambridge, 1993.

Pichevin, L., Cremer, M., Giraudeau, J., and Bertrand, P.: A 190 ky record of lithogenic grain-size on the Namibian slope: Forcing a tight link between past wind-strength and coastal upwelling dynamics, Mar. Geol., 218, 81-96, 2005.

Prahl, F. G. and Wakeham, S. G.: Calibration of unsaturation patterns in long-chain ketone compositions for paleotemperature assessment, Nature, 330, 367-369, 1987.

Prahl, F. G., Muehlhausen, L. A., and Zahnle, D. L.: Further evaluation of long-chain alkenones as indicators of paleoceanographic conditions, Geochim. Cosmochim. Acta, 52, 2303-2310, 1988.

Press, W. H., Flannery, B. P., Teukolsky, S. A., and Vetterling, W. T.: Numerical recipes in Pascal: The art of scientific computing, Cambridge Uni. Press, Cambridge, 1990.

Quartly, G. D. and Srokosz, M. A.: Eddies in the southern Mozambique Channel, Deep-Sea Pt. II, 51, 69-83, 2004.

Rau, A. J., Rogers, J., Lutjeharms, J. R. E., Giraudeau, J., LeeThorp, J. A., Chen, M. T., and Waelbroeck, C.: A 450-kyr record of hydrological conditions on the western Agulhas Bank Slope, south of Africa, Mar. Geol., 180, 183-201, 2002.

Richardson, P. L.: Agulhas Leakage into the Atlantic estimated with subsurface floats and surface drifters, Deep-Sea Res. Pt. I, 54, 1361-1389, 2007.

Schouten, M. W., de Ruijter, W. P. M., and van Leeuwen, P. J.: Upstream control of Agulhas Ring shedding, J. Geophys. Res., 107, 3109, doi:10.1029/2001JC000804, 2002.

Schouten, S., Hopmans, E. C., Schefuß, E., and Sinninghe Damste, J. S.: Distributional variations in marine crenarchaeotal membrane lipids: A new organic proxy for reconstructing ancient sea water temperatures?, Earth Planet. Sc. Lett., 204, 265-274, 2002.
Schouten, S., Huguet, C., Hopmans, E. C., Kienhuis, M., and Sinninghe Damste, J. S.: Analytical Methodology for TEX86 paleothermometry by high-performance liquid chromatography/atmospheric pressure chemical ionization-mass spectrometry, Anal. Chem., 79, 2940-2944, 2007.

Shannon, L. V.: The Benguela Ecosystem, 1. Evolution of the Benguela, physical features and processes, Oceanogr. Mar. Biol. Ann. Rev., 23, 105-182, 1985.

Sijp, W. P. and England, M. H.: The effect of a northward shift in the southern hemisphere westerlies on the global ocean, Prog. Oceanogr., 79, 1-19, 2008.

Sijp, W. P. and England, M. H.: Southern Hemisphere Westerly Wind Control over the Ocean's Thermohaline Circulation, J. Climate, 22, 1277-1286, 2009.

Stramma, L. and Lutjeharms, J. R. E.: The flow field of the subtropical gyre of the South Indian Ocean, J. Geophys. Res., 102, 5513-5530, 1997.

Suwa, M. and Bender, M. L.: Chronology of the Vostok ice core constrained by $\mathrm{O}^{2} / \mathrm{N}^{2}$ ratios of occluded air, and its implication for the Vostok climate records, Quaternary Sci. Rev., 27, 10931106, 2008.

Van Sebille, E., Biastoch, A., van Leeuwen, P. J., and de Ruijter, W. P. M.: A weaker Agulhas Current leads to more Agulhas leakage, Geophys. Res. Lett., 36, L03601, doi:10.1029/2008GL036614, 2009.

Vimeux, F., Masson, V., Jouzel, J., Stievenard, M., and Petit, J. R.: Glacial-interglacial changes in ocean surface conditions in the Southern Hemisphere, Nature, 398, 410-413, 1999.

Von Storch, H. and Zwiers, F. W.: Statistical analysis in climate research, Cambridge Univ. Press, Cambridge, UK, 735 pp., 1999.

Weijer, W., De Ruijter, W. P. M, and Dijkstra, H. A.: Stability of the Atlantic overturning circulation: competition between Bering Strait freshwater flux and Agulhas heat and salt sources, J. Phys. Oceanogr., 31, 2385-2402, 2001.

Weijer, W., De Ruijter, W. P. M., Sterl, A., and Drijfhout, S. S.: Response of the Atlantic overturning circulation to South Atlantic sources of buoyancy, Global Planet. Change, 34, 293-311, 2002.

Yoshimori, M., Weaver, A. J., Marshall, S. J., and Clarke, G. K. C.: Glacial termination: Sensitivity to orbital and $\mathrm{CO}_{2}$ forcing in a coupled climate system model, Clim. Dynam., 17, 571-588, 2001.

Zahn, R.: Beyond the $\mathrm{CO}_{2}$ connection, Nature, 460, 335-336, 2009. 